\title{
HODGKIN'S LYMPHOMA IN AN UNDER FIVE YEARS OLD CHILD: A CASE REPORT
}

\author{
Shyamali Datta1, Sharmishta Dutta², Panchanan Ghosh ${ }^{3}$
}

${ }_{1}^{1}$ Assistant Professor, Department of Paediatric Medicine, Mata Gujri Memorial Medical College, Kishanganj, Bihar.

${ }_{2}^{2}$ Post Graduate Student, Department of Paediatric Medicine, Mata Gujri Memorial Medical College, Kishanganj, Bihar.

3 Professor, Department of Paediatric Medicine, Mata Gujri Memorial Medical College, Kishanganj, Bihar.

\section{ABSTRACT}

Lymphoreticular malignancy is an important group of neoplasm in paediatric age group. It constitutes about $15 \%$ of malignancy in children.

\section{CASE REPORT}

A girl child aged 4 years presented with complaints of slow painless progressive swelling arising from the anterior aspect of the neck for last 2 years, which started as a small nodule on right side of the neck, but gradually increased to present size. On examination swelling was large sized, irregular shape, rubbery in feel, not moving very freely and not attached to skin. X-ray chest showed extensive mediastinal and parahilar lymphadenopathy. FNAC shows binocular cells with prominent nucleoli are seen, which are suggestive of 'Reed Sternberg cells.' Chemotherapy started for the patient and six-month follow-up shows reduction of lymph node size.

\section{DISCUSSION}

Though Non-Hodgkin's lymphoma is seen more commonly in children, but Hodgkin's disease is a rare presentation.

\section{KEYWORDS}

Lymphoreticular Malignancy, Hodgkin's Disease.

HOW TO CITE THIS ARTICLE: Datta S, Dutta S, Ghosh P. Hodgkin's lymphoma in an under five years old child: a case report. J. Evolution Med. Dent. Sci. 2016; 5(48):3108-3109, DOI: 10.14260/jemds/2016/721

\section{INTRODUCTION}

Lymphoreticular malignancy is an important group of neoplasm in paediatric age group. It constitutes about $15 \%$ malignancies in children. ${ }^{1}$ However, distribution of types depends largely on the geographical pattern. ${ }^{1}$ Though nonHodgkin's lymphoma is seen more commonly, but Hodgkin's disease is not frequent.

\section{CASE REPORT}

A girl child aged 4 years presented with history of slow, painless, progressive swelling arising from the anterior aspect of the neck region for last 2 years. It was started as a small nodule on the right side of the neck, but gradually encroached upon both halves of front of neck and also the sides. For last one year, there was low-grade fever present for some days followed by febrile intervals, night sweating, cough and pruritus over the whole body. For last six months, there is respiratory difficulty and significant weight loss too.

On examination the swelling was large sized, irregular shape, rubbery in consistency, not moving freely and not attached to skin. It was not a thyroid lump. Axillary or inguinal lymph nodes are not enlarged. There are no hepatosplenomegaly.

On routine blood examination, $\mathrm{Hb} \%$ was $7.5 \mathrm{gm} / \mathrm{dL}$. TLC10,400/cmm. (DLC: neutrophil-60\%, lymphocyte-38\%, monocyte-1\%, eosinophil-1\%), ESR $68 \mathrm{~mm}$ (1st hr). Thyroid hormone and TSH were normal. HIV was non-reactive.

Financial or Other, Competing Interest: None

Submission 30-11-2015, Peer Review 01-12-2015,

Acceptance 18-01-2016, Published 16-06-2016.

Corresponding Author:

Dr. Shyamali Datta

Ashirvad Apartments, Khudiram Sharani,

Coochbehar-736101, West Bengal

E-mail: nil148.g@gmail.com

DOI: $10.14260 /$ jemds $/ 2016 / 721$
FNAC shows various populations of lymphoid cells. On CT scan, it was graded as stage 2 according to Ann Arbor staging. Mononuclear cells and eosinophils seen at a few places. Binocular cells with prominent nucleoli are seen, which are suggestive of "Reed Sternberg cells" and there was Nodular Sclerosing type lymphocyte. All these features are suggestive of Hodgkin's Lymphoma. The patient treated by six cycles of chemotherapy with 15 to 25.5 Gray involved-field radiation. Patient was cured on followup.

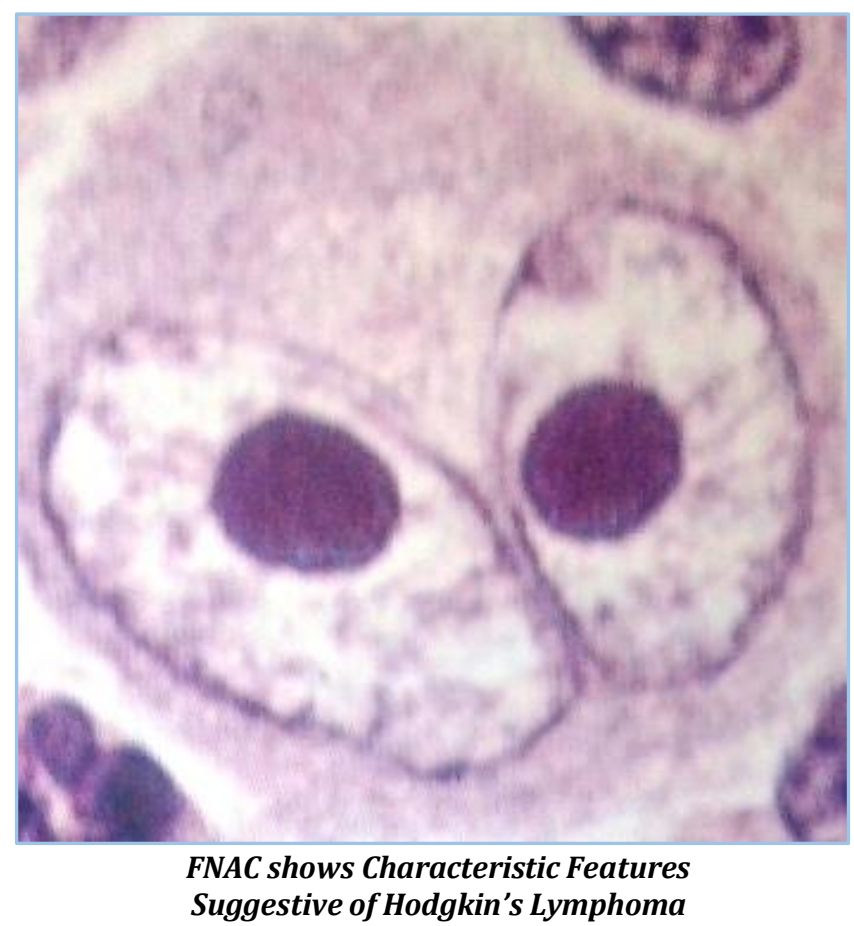




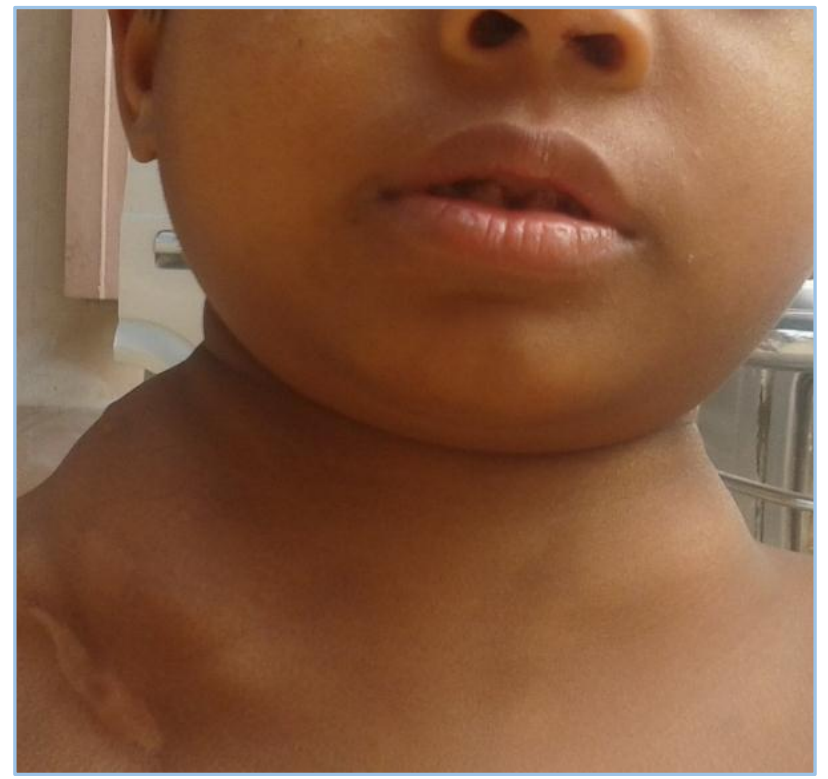

Showing Extensive Swelling Arising from Neck

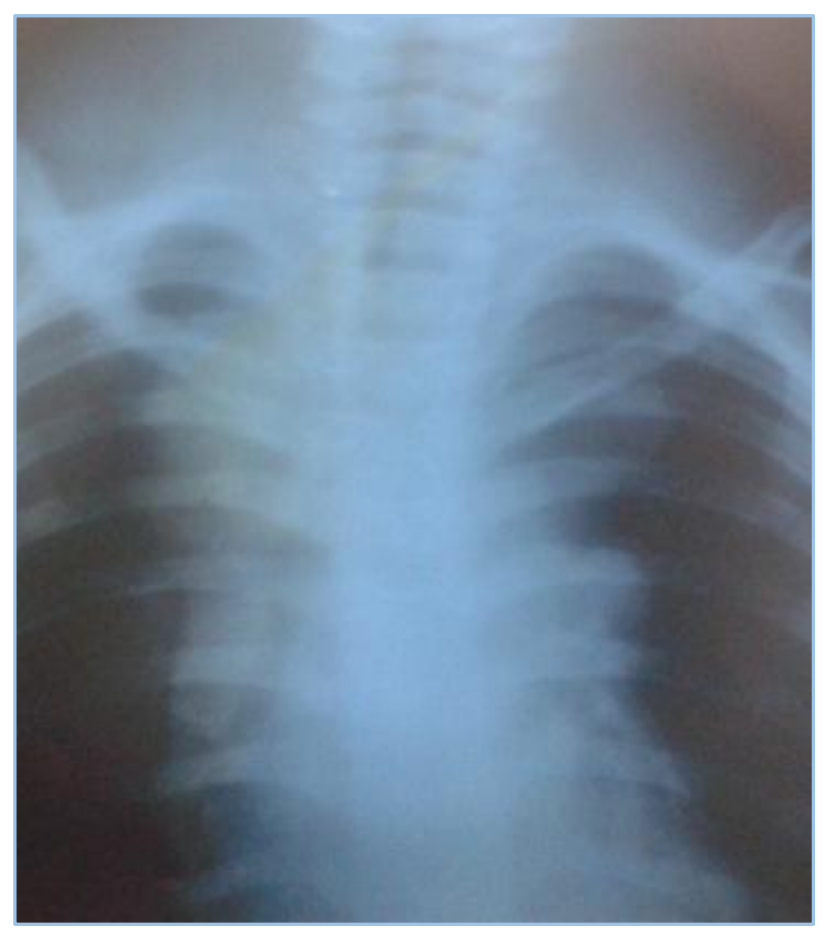

$X$-ray Chest (PA View) showing Enlargement of Mediastinal \& Parahilar Lymph Nodes

\section{DISCUSSION}

The incidence of Hodgkin's lymphoma by age show a bimodal distribution. In developed nations, the first peak occurs at approximately age 20 years and the second peak is observed in patients aged 55 years or older. Hodgkin lymphoma is uncommon before age 5 years. ${ }^{2}$ However, in developing countries, the first peak is shifted into childhood, usually before adolescence. Male predominance is seen in all the studies. $^{2}$ but here it is a female child. Asians have considerably lower rates than whites and blacks for Hodgkin lymphoma unlike our case. ${ }^{3}$

In our case, the dominant clinical presentation is neck swelling. In a study by Whittemore KR et al, some typical features e.g. cyclical fever, night sweating, pruritus also seen in our case. 4 As regards to staging of the case, more than two lymph nodes are detected on one side of diaphragm may be in stage 2 of Ann Arbor staging. 'Reed Sternberg cells' confirmed the diagnosis of Hodgkin's lymphoma. ${ }^{6}$ As per the study by Maureen M. O'Brien et al, patient was treated by chemotherapy, but unlike to the study no secondary neoplasm observed during followup. ${ }^{7}$

\section{REFERENCES}

1. Lymphoma HP, DeAlarcon PA. Chief Editor: Robert J Arceci, http://emedicine.medscape.com/article/987101overview\#a5.

2. MacGregor FB. Tumours of the head and neck in childhood. In: Michael Gleeson. Scott-Brown's Otorhinolaryngology, head and neck surgery, $7^{\text {th }}$ ed. Great Britain: Hodder Arnold 2008:1254.

3. Morton LM, Wang SS, Devesa SS, et al. Lymphoma incidence patterns by WHO subtype in the United States, 1992-2001. Blood 2006;107(1):265-76.

4. Whittemore KR, Cunningham MJ. Malignant tumours of the head and neck. In: Bluestone CD, Stool SE (eds). Paediatric otolaryngology, $4^{\text {th }}$ ed. Philadelphia: Saunders, 2003:170336.

5. Lister TA, Crowther D, Sutcliffe SB, et al. Report of a committee convened to discuss the evaluation and staging of patients with Hodgkin's disease: cotswolds meeting. Journal of clinical oncology 1989;7(11):1630-6.

6. Corbett R, Pritchard J, Plowman PN. Tumours of the head and neck. In: Michael Gleeson. Scott-Brown's Otorhinolaryngology, Head and Neck Surgery, $6^{\text {th }}$ ed. Great Britain: reed educational and professional publishing Ltd 1997:6.

7. O'Brien MM, Donaldson SS, Balise RR, et al. Second malignant neoplasms in survivors of paediatric Hodgkin's lymphoma treated with low-dose radiation and chemotherapy. Journal of clinical oncology 2010;28(7):1232-9. 